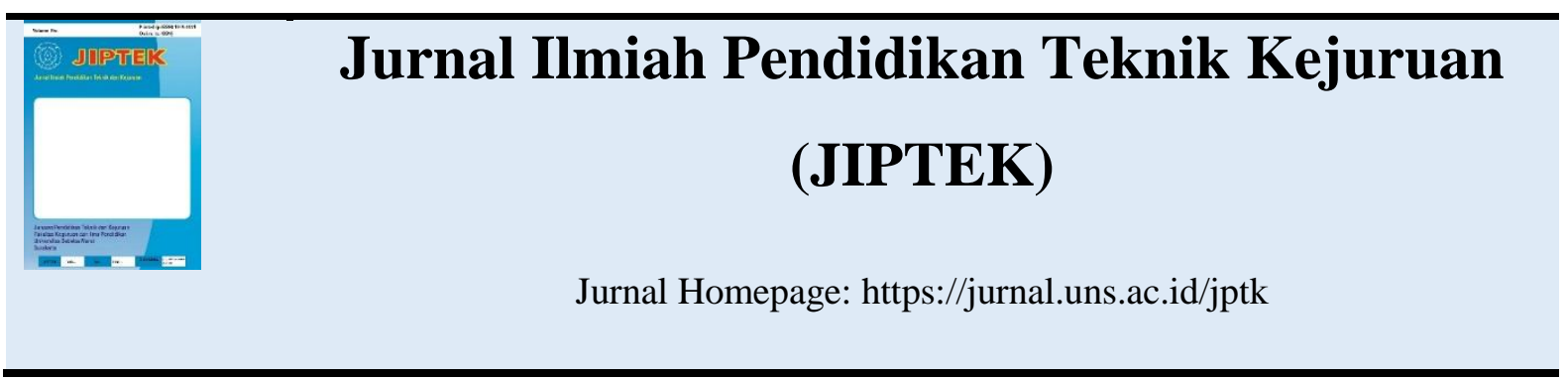

\title{
EFEKTIFITAS KEPEMIMPINAN VOKASI UNTUK PRODUKTIVITAS PEMBANGUNAN SUMBER DAYA MANUSIA DI BALAI LATIHAN KERJA
}

\author{
Ilham Akbar Darmawan', Didik Aribowo², Desmira ${ }^{3}$, Ratna Ekawati ${ }^{4}$ \\ 1,2,3,4 Jurusan Pendidikan Vokasional Teknik Elektro FKIP UNTIRTA \\ Email: $\underline{\text { ilham.ad@untirta.ac.id }}$
}

\begin{abstract}
ABSTRAK
Pendidikan vokasi adalah bidang pendidikan yang menekankan tujuan pendidikan pada kemampuan dan skill sebagai bekal bagi peserta didik untuk melanjutkan kehidupan. Institusi pengelola pendidikan vokasi -dalam hal ini Balai Latihan Kerja (BLK)- harus memiliki pengelolaan yang baik dan efektif dalam menjalankan program. Kajian ini bertujuan untuk mengetahui aspek-aspek yang harus diperhatikan dalam pengelolaan pendidikan vokasi sebagai wujud pembangunan sumber daya manusia. Dari berbagai literatur yang dikaji, terdapat beberapa faktor yang mempengaruhi pencapaian keberhasilan dalam pengelolaan pendidikan vokasi antara lain: kepemimpinan dan tipe instansi pendidikan, penguasaan dan kompetensi, gender, dan kondisi masyarakat dan sosial budaya. Berbagai faktor tersebut, secara teoritis ternyata sangat berpengaruh terhadap efektivitas kepemimpinan dan juga produktivitas dalam pembangunan sumber daya manusia
\end{abstract}

Kata kunci: efektivitas, kepemimpinan, sumber daya manusia, balai latihan kerja

\begin{abstract}
Vocational education is the field of education that emphasizes the purpose of education in abilities and skills as a provision for students to continue their lives. The institution that manages vocational education (in this case the vocational training center) must have good and effective management in running the program. This study aims to determine the aspects that must be considered in managing vocational education as a manifestation of human resource development. From the various literature reviewed, several factors that influence the achievement of success in managing vocational education, among others: leadership and types of educational institutions, mastery and competency, gender, and community and sociocultural conditions. These various factors, theoretically, are very influential on leadership effectiveness and productivity in the development of human resources.
\end{abstract}

Keywords: effectiveness, leadership, human resources, vocational training center

\section{PENDAHULUAN}

Kepemimpinan merupakan pembahasan yang sejak lama diperbincangkan dan menarik perhatian. Setiap pemimpin memiliki gaya yang dianggap tepat dalam menjalankan kepemimpinannya. Menurut Wonacott (2001:1) perkembangan kepemimpinan dibutuhkan sebagai upaya dalam menemukan konsep terbaik dalam mengelola suatu lembaga seperti pendidikan, perusahaan maupun kafir. 
Kepemimpinan memiliki peranan penting dalam pengelolaan pendidikan baik lembaga pendidikan formal maupun non-formal. Halim (2015:48) mengatakan bahwa kepemimpinan merupakan faktor utama dalam pencapaian tujuan pendidikan. Hal menegaskan bahwa kepemimpinan merupakan sesuatu yang harus mendapat perhatian serius jika cita-cita pendidikan hendak dicapai. Akan tetapi, gaya kepemimpinan merupakan sesuatu yang tidak absolut sepanjang zaman. Kepemimpinan dalam pendidikan harus sesuai dengan perkembangan zaman yang sangat dinamis dan berkelanjutan. Hal ini dikarenakan pendidikan sangat terpengaruh dengan berbagai pengaruh dari luar yang tidak terbatas (Halim, 2015:47). Dengan demikian, kepemimpinan dalam penyelenggaraan dapat diartikan sebagai pengendali arah gerak pendidikan agar dapat mencapai tujuan yang telah ditetapkan.

Sebagai upaya pembangunan sumber daya manusia, pendidikan merupakan salah satu pilar utama untuk mewujudkan cita-cita tersebut. Sebagai negara terbesar di Asia Tenggara, Indonesia memiliki tantangan tersendiri dalam konteks memajukan kualitas sumber daya manusianya. Hal ini berkaitan erat dengan jumlah populasi yang sangat besar dan juga kondisi geografis Indonesia. Selain itu, Indonesia juga memiliki beban moral untuk menjadi negara terdepan dalam menyongsong gerakan ekonomi khususnya di kawasan ASEAN sesuai program Presiden Joko Widodo dalam upaya mendobrak gerakan ekonomi kerakyatan. Pembangunan sumber daya manusia untuk mendukung gerakan ekonomi kerakyatan tersebut tentunya membutuhkan pengelolaan yang serius dari pemerintah sebagai pelayan masyarakat yang menjadi pelaku dalam bergulirnya persaingan global di kawasan ASEAN.

Pemerintah di bawah kepemimpinan Presiden Joko Widodo menyatakan bahwa pendidikan di Indonesia harus di arahkan kepada pendidikan yang mengantarkan peserta didik pada keterampilan dan skill yang mumpuni sebagai bekal untuk bersaing di Asia Tenggara. Pendidikan yang mengarahkan peserta didik itu pada keterampilan disebut sebagai pendidikan vokasi (Baharuddin, 2012:1). Di Indonesia, terdapat berbagai lembaga pengelola pendidikan vokasi. Berbagai lembaga tersebut berada di bawah naungan kementerian yang berbeda pula, antara lain SMK di bawah Kementerian Pendidikan dan Kebudayaan yang menyelenggarakan pendidikan vokasi secara formal, dan Kementerian Tenaga Kerja dan Transmigrasi yang menyelenggarakan pendidikan secara nonformal.

Lembaga pengelola pendidikan vokasi nonformal di Indonesia adalah Balai Latihan Kerja (BLK) yang berada di bawah koordinasi Direktorat Jendral Pembinaan dan Pengembangan Produktivitas Kementerian Tenaga Kerja dan Transmigrasi. Tujuan dari BLK adalah memberikan ruang bagi masyarakat untuk mengembangkan diri dan meningkatkan kompetensi dan kecakapan hidup (life skill). Peningkatan dan pengembangan kecakapan hidup tersebut dilaksanakan melalui programprogram pendidikan dan pelatihan yang berbasis pada kecakapan hidup atau keterampilan. Dengan penerapan sistem pendidikan dan pelatihan tersebut, diharapkan akan terjadi 
kesinambungan antara pertumbuhan ekonomi, informasi ketersediaan pasar kerja dan juga menjamin (a) individu dan perusahaan dapat menyesuaikan diri dengan perubahan ekonomi, (b) manfaat kemajuan ekonomi mengucur kepada seluruh rakyat. (ILO, 2011:i)

Pada dasarnya, kepemimpinan dalam pendidikan merupakan serangkaian tindakan dalam hal pengelolaan pendidikan dan berbagai hal lain yang dapat menjadi pendukung atau dapat juga menjadi penghambat dalam pencapaian tujuan pendidikan tersebut (Sehfudin, 2011:2). Oleh karena itu, kepemimpinan dalam pendidikan vokasional merupakan puncak dari segala kompleksitas yang membutuhkan pengaturan dan manajemen yang baik guna mencapai hasil yang optimal dalam pengelolaan pendidikan tersebut.

Ali Syariati (1987:8) mengatakan bahwa selama definisi tentang manusia belum disepakati secara jelas, maka pendidikan bagaimanapun canggihnya tidak akan dapat mengantarkan manusia pada kemanusiaannya. Dengan demikian, dibutuhkan sebuah kesepakatan terhadap makna kemanusiaan yang pada gilirannya akan mengarahkan suatu kebutuhan akan pendidikan, dan pendidikan membutuhkan suatu pengelolaan yang jelas dan sistematis. Kepemimpinan vokasi merupakan sistematika struktur pengelolaan pendidikan vokasi yang menggambarkan sebuah konsep sebagai pedoman pengelolaan pendidikan. Konsep kepemimpinan telah menarik perhatian banyak peneliti untuk memberikan rekomendasi pemecahan masalah kepemimpinan dalam pendidikan vokasi. Hal ini dikarenakan akan keyakinan bahwa masa depan bangsa ditentukan oleh kesuksesan pendidikan. Oleh karena itu, pemimpin lembaga pendidikan vokasional memiliki peranan yang sangat penting untuk meningkatkan pencapaian dari tujuan tersebut.

Indonesia sebagai negara dengan sejarah panjang gaya kepemimpinan tentu meninggalkan sebuah "konsep lama" yang secara alamiah tertanam dalam mindset anak bangsa dan menjadi budaya. Gaya kepemimpinan yang paling dominan adalah gaya kepemimpinan klasik yang kaku dan cenderung memanifestasikan nilai-nilai otoritarianisme. Gaya kepemimpinan tersebut menjadi tidak relevan dengan situasi dan kondisi yang terus berubah sesuai perkembangan zaman seperti masa sekarang.

Berbagai literatur menyatakan teori, gaya atau pendekatan kepemimpinan lebih fokus kepada individu atau perorangan sebagai pimpinan. Akan tetapi, sejalan dengan perkembangan zaman, gaya kepemimpinan yang berfokus pada individu dianggap sudah tidak relevan lagi (Halim, 2015:50). Hallinger, Bickman dan Davies (1996:530) menegaskan bahwa sangat tidak rasional seorang pemimpin di lembaga pendidikan mampu melakukan perubahan dan perbaikan secara sendirian. Oleh karena itu, dalam upaya untuk menemukan sebuah konsep baru yang membangun penulis melakukan pengkajian terhadap beberapa gaya kepemimpinan alternatif.

Menurut Miftah Toha dalam Sehfudin (2011:8) pengertian gaya kepemimpinan adalah suatu cara yang dipergunakan oleh seorang pemimpin dalam mempengaruhi perilaku orang lain. Senada dengan pernyataan sebelumnya, Sunarcaya (2008:14) menyatakan bahwa gaya 
kepemimpinan adalah bagaimana cara mengendalikan bawahan untuk melaksanakan sesuatu. Regina (2010:71) juga menyatakan bahwa gaya kepemimpinan adalah perilaku dan strategi, sebagai hasil kombinasi dari falsafah, ketrampilan, sifat, sikap, yang sering diterapkan seorang pemimpin ketika ia mencoba mempengaruhi kinerja bawahannya. Kepemimpinan merupakan faktor yang sangat penting dan bagaimana caranya seseorang memimpin hingga dapat membawa kelompok kerja ke arah keberhasilan yang maksimal.

Dari pendapat tersebut dapat disimpulkan bahwa gaya kepemimpinan adalah Suatu cara yang dipergunakan oleh seorang pemimpin dalam mempengaruhi, mengarahkan, mendorong dan mengendalikan orang lain dalam mencapai suatu tujuan.

\section{a. Kepemimpinan Distributif}

Kepemimpinan distributif merupakan gaya kepemimpinan yang cenderung meyakini bahwa kepemimpinan tidak hanya berfokus pada perseorangan. Menurut Elmor dalam Halim (2015:50) kepemimpinan distributif memiliki lima aspek antara lain, (1) Kesepakatan akan tujuan, (2) budaya tempat pendidikan, (3) tanggung jawab bersama, (4) pembangunan profersionalisme dan (5) tradisi kepemimpinan. Selain itu, MacBeath (2000:352) menyatakan bahwa tradisi kepemimpinan distributif merupakan sebuah tradisi kepemimpinan yang formal, praktis, efektif dan berkembang secara progresif. Spalline (2006) juga menegaskan bahwa ciri kepemimpinan distributif adalah kepemimpinan yang melibatkan pemimpin, pengikut dan situasi ataupun konteks yang sedang dihadapi dan menjadi tantangan dalam penyelenggaraan pendidikan.

Dengan demikian, dapat disimpulkan bahwa kepemimpinan distributif merupakan gaya kepemimpinan yang memberikan ruang akan kedatangan ide untuk perbaikan dari mana saja, kepemimpinan distributif diwujudkan melalui kolaborasi yang solid antara pemimpin maupun anggota yang membuat kepemimpinan ini menjadi gaya kepemimpinan yang kolektif dan juga sesuai dan selaras dengan konteks yang mengintervensi penyelenggaraan program pendidikan vokasi tersebut.

\section{b. Kepemimpinan Transformatif}

Kepemimpinan transformatif di cetuskan pertama kali oleh Downton dan di kembangkan oleh Burns. Menurut Burns dalam Temple (2001:43) kepemimpinan transformatif dan transaksional cenderung mengambil bekerja pada rentang akhir kepemimpinan. Sebaliknya, Beck dan Yeager (1989:21) menyatakan bahwa paradigma kepemimpinan transformatif merupakan kepemimpinan yang menghendaki perubahan dan perbaikan yang pada gilirannya menekankan kepemimpinan ini pada demokrasi, partisipatif, dan berorientasi pada perhatian. Beck dan Yeager (1997:23) menegaskan bahwa kepemimpinan transformatif sebagai improvisasi dari kepemimpinan transaksional. Indikator dari kepemimpinan transformatif antara lain yaitu : atribut ideal, perilaku ideal, motivasi, berbasis pada penyelesaian masalah, dan juga pertimbangan individual. 
Dengan demikian, kepemimpinan distributif merupakan gaya kepemimpinan yang penuh dengan pertimbangan dalam pengambilan keputusan. Kepemimpinan transformatif menekankan kematangan konsep yang ideal dan melibatkan seluruh anggota dalam memecahkan sebuah persoalan.

\section{c. Kepemimpinan Natural}

Kepemimpinan Natural atau kepemimpinan alami adalah sebuah gaya kepemimpinan yang berorientasi pada kesadaran -dalam bertindak dan mengambil keputusan- setiap anggota sebuah organisasi. Andrew Bell dalam Avery (2004:171-187) menyatakan bahwa kepemimpinan natural berlandaskan pada empat prinsip yaitu : (1) keadilan, dimaksudkan pada perlakuan terhadap orangorang yang terpimpin, setiap anggota di pandang setara dan memiliki potensi yang sama (2) kebebasan, dimaksudkan pada keluesan anggota dalam berkreasi dan mengajukan sebuah gagasan untuk perbaikan (3) komitmen dan tanggung jawab, dimaksudkan kepada kesungguhan akan sebuah keputusan dan penyelesaiannya (4) Alamiah, dimaksudkan kepada pengambilan keputusan yang sesuai konteks.

Kepemimpinan natural tidak memliliki bagan struktur organisasi dan detil pekerjaan yang spesifik dan jelas kecuali pada level yang tinggi. Kepemimpinan pada gaya ini lahir dari munculnya sebuah ide terbaik dan kepengikutan terhadap ide tersebut. Gaya komunikasi sangat santai dan jauh dari kata formal.
Kepemimpinan ini menyatakan beorientasi pada tujuan dan cara mencapainya dengan kesenagan dan kegembiraan.

Bell dalam Avery (2004:171-187) juga menjelaskan bahwa komunikasi kerja dalam gaya kepemimpinan ini antara lain: (1) tidak tetap, yaitu penugasan yang sangat jauh dari otoritarianisme pimpinan, (2) saling mendukung dan tidak ada istilah "bos", (3) kepemimpinan berlandaskan pada kepengikutan akan ide terbaik dari setiap anggota, (4) segala sesuatu didasari pada komitmen kesukarelaan dan sangat natural.

Dengan demikian, kepemimpinan natural dapat di definisikan sebagai gaya kepemimpinan yang tidak menonjolkan status pemimpin sebagai pihak yang harus dipatuhi. Kepemimpinan natural menjujung tinggi ide dan gagasan egalitarianisme pemimpin dan kerendahan hati serta bertujuan untuk membangun budaya "sadar" akan tanggung jawab dan komitmen yang telah disepakati.

\section{METODE PENELITIAN}

Penelitian ini merupakan penelitian studi pustaka. Menurut Zed (2004:17) penelitian sudi pustaka memerlukan langkah-langkah antara lain: 1. Menyiapkan perlengkapan; 2. Menyusun bobliografi kerja; 3. Mengatur waktu dan 4 . Membaca dan menganalisis literature. Berdasrkan pendapat di atas, penelitian ini disusun dengan langkah-langkah sebagai berikut: 


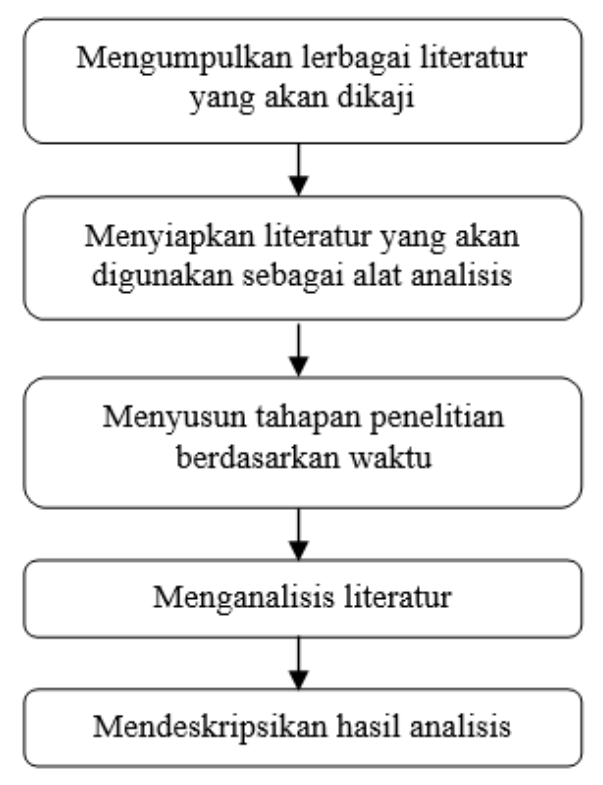

Gambar 1. Langkah-langkah penelitian

\section{HASIL PENELITIAN DAN PEMBAHASAN}

Implemntasi pendidikan vokasional tidak bisa dilepaskan dari gaya kepemimpinan yang merupakan cara dan strategi pengelolaan pendidikan vokasi agar mencapai tujuan. BLK sebagai lembaga pendidikan vokasi perlu mendapat perhatian serius agar pengelolaannya dapat dioptimalkan, maka dari itu dibutuhkan kapemimpinan yang tepat dan efektif dalam tubuh lembaga tersebut. Untuk menjadi pemimpin, seseorang harus memiliki nilai yang kuat dalam pribadi mereka, seperti kecerdasan, kemampuan memecahkan masalah, kemampuan menginterpretasi keadaan sebagai landasan kebijakan yang diambil, dan wawasan yang luas. Kirkpatrick \& Locke dalam Kayan (2016:2) menegaskan bahwa terdapat enam karakter ataupun sifat yang membedakan seorang pemimpin dengan yang bukan pemimpin, karakter tersebut antara lain yaitu; tujuan, motivasi, integritas, kepercayaan diri, intelektualitas (kognisi), dan pengetahuan terhadap tugas-tugas yang di emban. hal ini menujukkan bahwa seorang pemimpin harus memiliki keunggulan dibanding orang-orang yang di pimpin.

Dalam hal pencapaian tujuan pendidikan vokasi, terdapat berbagai unsur yang harus diperhatikan antara lain adalah: (1)kondisi masyarakat yang mengharuskan terbangunnya gaya komunikasi yang baik dalam penyelenggaraannya. Hal ini sangat dibutuhkan mengingat gaya komunikasi merupakan unsur mendasar dari sebuah interaksi tak terkecuali interaksi dalam pembelajaran vokasi. (2) Menekankan aspek vokasi berlandaskan pada kurikulum yang sesuai dengan keinginan masyarakat untuk memiliki keahlian yang akan digunakan sebagai sarana mendapatkan pekerjaan dan pada muaranya akan meningkatkan perekonomian dan kemajuan negara. Dari kedua aspek tersebut, dapat ditarik kesimpulan bahwa gaya kepemimpinan memiliki keterkaitan yang sangat erat dalam pencapaian tujuan dari pendidikan vokasi. Perbedaan mendasar pada pendidikan vokasi dengan pendidikan umum adalah pada orientasi dan tujuan penyelenggaraannya. Pendidikan vokasi menekankan aspek keahlian dan skill yang dengan kata lain pendidikan vokasi menganut aliran pragmatis yang merupakan ciri pendidikan orang dewasa yaitu belajar untuk bekerja.

Pendidikan vokasi terdiri dari tiga landasan yaitu memenuhi keinginan masyarakat akan pekerjaan, memberikan pilihan yang lebih luas dalam dunia pendidikan, dan sebagai upaya memberikan motivasi yang tinggi untuk memperbaiki berbagai bentuk pembelajaran. 
Oleh karena itu dibutuhkan pula gaya kepemimpinanan yang relevan dengan tujuan dan orientasi tersebut agar pencapaian dalam penyelenggaraan pendidikan vokasi optimal.

Pendidikan vokasi merupakan aliran pendidikan yang mampu membentuk dan melahirkan orangorang yang mahir dan kompeten dalam industri. Knut Philips (1992:34) mengatakan bahwa pendidikan vokasi merupakan suatu pendidikan yang paling unggul dalam bidang pekerjaan. Pernyataan ini menegaskan bahwa individu yang terlibat dalam pendidikan vokasi memiliki pengetahuan dan keterampilan yang baik dalam menguasai suatu bidang pekerjaan. Untuk mencapai kompetensi yang baik bagi setiap peseerta didik, tentu dibutuhkan pengelolaan yang matang dan interaksi yang baik pula. Hal tersbut hanya dapat dicapai dengan kualitas kepemimpinan atau pengelolaan yang baim terhadap sebuah lembaga pendidikan vokasi.

\section{a. Kepemimpinan dan tipe instansi}

\section{pendidikan}

Jenis instansi tentu sangat mempengaruhi gaya kepemimpinan yang akan diterapkan agar sebuah institusi tersebut dapat mencapai tujuan yang telah di tetapkan.

Kemenakertrans melalui Ditjen Binalattas membagi kategori BLK menjadi tiga bagian yaitu, balai besar yang pengelolaannya langsung dibawah kementerian, balai dibawah pengelolaan pemerintah daerah provinsi (sedang), dan balai dibawah pengelolaan pemerintah daerah kabupaten (kecil). Tucker (1992:21) mengatakan bahwa ukuran institusi ataupun lembaga mempengaruhi bagaimana pemimpin dan gaya kepemimpinannya membuat sebuah keputusan. Ukuran kelembagaan sangat bervariasi akan tetapi substansi dari kepemimpianan adalah sama. Terlepas dari ukuran-ukuran tersebut, setiap pemimpin memiliki wewenang, kekuasaan dan tanggung jawab yang mengharuskan kepemimpinan melakukan berbagai tindakan untuk pencapaian tujuan.

Pendidikan vokasional dengan kapasitas yang besar dan memiliki banyak pengelola hendaknya menerapkan model kepemimpinan distributif. Kepemimpinan model ini sangat tepat karena ukuran dan kapasitas yang besar membutuhkan sebuah stuktur yang detil, pembentukan budaya pendidikan yang bertanggung jawab dan membangun sebuah tradisi kepemimpinan yang kompleks. Dalam hal tanggung jawab, kapasitas besar sebuah lembaga menuntut seorang pemimpin untuk memiliki kecakapan yang tinggi pula, oleh karena itu kepatuhan terhapat struktur kepemimpinan yang didasari pada kesadaran kolektif setiap angota akan memberikan dampak yang baik. Hal yang perlu diperhatikan adalah tanggung jawab pemimpin tertinggi merupakan seseuatu yang harus di tanggungjawabi pula oleh anggota atau pengelola lainnya. Kepemimpinan distributif memberkan ruang untuk mengkreasikan sebuah ide atau gagasan di setiap aspek yang mengikat sebuah gaya kepemimpinan. Sedangkan dari segi orientasi, kapasitas yang besar menuntut sebuah upaya kerjasama yang seragam agar setiap aspek yang terkait dalam sebuah kapasitas (sistem) yang besar tersebut dapat mencapai tujuan bersama. 
Untuk lembaga atau institusi dengan kapasitas yang sedang gaya kepemimpinan yang tepat adalah kepemimpinanyang transformatif. Hal ini di anggap tepat karena ciri dari kepeimipinan transformatif sangat relevan dengan kapasitas yang tidak terlalu besar namun juga tidak kecil. Kepemimpinan tranformatif merupakan gaya kepemimpinan yang fokus pada perbaikan sebuah sistem yang dikelola. Inti dari kepemimpinan ini adalah improvisasi sebuah sistem yang mengikat. Tidak bisa dinafikan bahwa gaya kepemimpinan ini dapat di terapkan pada kapasitas besar dan kapasitas kecil, akan tetapi ciri dari gaya kepemimpinan ini yang berorintasi pada demokrasi, perhatian dan partisipatif sangat sesuai dengan kapasitas yang sedang. Intinya, gaya kepemimpinan transformatif merupakan gaya kepmimpinan yang mengedepankan partisipasi anggota namun juga tidak menabaikan struktur. Dalam hal tanggung jawab, kepemimpinan ini menitikberatkan pada pucuk pimpinan akan tetapi segala keputusan yang di ambil tersebut merupakan hasil dari pengamatan dan perhatian terhadap seluruh anggota.

Untuk lembaga atau institusi yang berkapasitas kecil, gaya kepemimpinan natural di anggap yang paling tepat untuk di terapkan. Hal ini dilandasi pada ciri kepemimpinan natural yang mengedepankan pencapaian tujuan dan kegembiraan dalam pelaksanaannya. Selian itu Bell dalam Avery (2004:184) juga menegaskan bahwa kepemimpinan natural hanya akan efektif jika di terapkan pada kelompok organisasi kecil. Gaya kepemimpinan ini menekankan empat aspek yang menyokong kepemimpinan yaitu: (1) Keadilan, dimana dalam implementasi seluruh anggota di anggap memiliki potensi yang sama dan juga memiliki kesempatan yang sama untuk memberikan ide atau gagasan untuk kemajuan institusi. (2) kebebasan, yaitu pemberian ruang untuk berkreasi kepada seluruh anggota, Bell dalam Avery (2004:179) mengatakan bahwa kebebasan akan membuka ruang untuk pengembangan potensi, dan sebaliknya perintah yang otoriter akan menghambat perkembangan akal dalam berkreasi. (3) Komitmen dan tanggung jawab, hal ini mnekankan bahwa dalam gaya kepemimpinan ini yang terpenting adalah komitmen yang datang dengan kerelaan hati (tanpa tekanan dan intervensi dari berbagai pihak). Dengan begtu, setiap anggota akan bekerja dengan penuh tanggung jawab tanpa tekanan. (4) konsep waterline, keputusan yang diambil lahir secara alamiah, mengalir seperti air. Maksudnya, keputusan yang di ambil dalam gaya kepemimpinan ini berkaitan erat dengan konteks dan kondisi di lapangan.

Gaya kepemimpinan natural juga sangat lues dan tidak kaku. Komunikasi dalam gaya ini berlangsung dari individu-ke individu tanpa perantara, tidak ada boss dan anggota. Gaya kepeimpinan ini didefenisikan dari kecmerlangan ide dan gagasan serta kepengikutan yang mendukung gagasan terbaik. Apabila dikaitkan dengan lembaga pendidikan vokasional, gaya ini akan menyesuaikan konteks dan kondisi di 
lapangan dan mengkonversikannya menjadi sebuah tujuan yang harus dicapai.

Dari berbagai tipe institusi yang telah dijalaskan di atas, tujuan dari singkroisasi gaya kepemimpinan adalah untuk efektifitas kepemimpinan. Hal tersebut dilakukan karena efektifitas dibutuhkan sebagai upaya pencapaian tujuan denagn baik dan tepat. Dengan deamikian, efektivitas menjadi bagian yang sangat penting dalam implementasi gaya kepemimpinan untuk mencapat tujuan pendidikan yang telah ditetapkan.

\section{b. Penguasaan dan Kompetensi}

Penguasaan dalam kepemimipinan terkait erat dengan kapasitas seorang pemimpin, dan kapasitas kepemimpinan itu dapat lahir secara alamiah dari pengalaman-pengalaman. Seagren et al (1994:13) mengatakan bahwa dalam perspektif kepemimpinan, pengetahuan akan berbagai dimensi dalam lingkup pekerjaan sangat dibutuhkan mengingat akan banyaknya masalah yang dihadapai, dan pengetahuan itu lahir dari pengalaman. Hal ini menegaskan bahwa pemimpin suatu institusi harus memiliki pengetahuan yang luas dan mendalam terkait dimensi-dimensi yang berkaitan dengan kepemimpinan (lembaga yang dipimpinnya).

Pengetahuan syarat akan pengalaman, maka dibutuhkan pertimbangan yang matang dalam penunjukan kepemimpinan dalam penididikan vokasional. Ini menjadi penting karena substansi dari pendidikan vokasional sendiri adalah kepakaran dan kompetensi. Maka seluruh rangkaian aspek yang menjadi sistem dalam kepemimpianan harus dikuasai dengan sangat matang. Gaya kepemimpinan distributif, transfromatif dan natural merupakan gaya kepemimpinan yang dapat menjadi solusi dalam mengatasi permasalahan ini karena gaya kepemimpinan tersebut sangat membuka ruang partisipasi akan seluruh anggota. Dengan demikian, pengetahuan yang berbasis pengalaman bisa datang dari mana saja, bukan hanya pemimpin tertinggi.

\section{c. Kepemimpinan dan Gender}

Gender merupakan salah satu aspek yang tidak bisa dilepaskan dari bahasan kepemimpinan, terlebih lagi kepemimpinan vokasional yang sangat syarat dengan gender karena bidang keahlian vokasional yang sangat luas. Helgesen (1990) mengaytakan bahwa perempuan dan laki-laki memlikiperbedaan gaya kepemimpinan dan sudut pandang dalam memimpin, akan tetapi perbedaan perbedan pandangan tersebut diperlukan untuk disesuaikan dengan kepemimpinan dalam lembaga.

Tidak bisa dimungkiri, Pendidikan vokasional memiliki berbagai bidang yang secara alamiah terbentuk dari kesesuaian gender. Kepemimpinan dan gender sangat penting karena ada susut pandang dimana laki-laki lebih jeli dan ada pula aspek dimana sudut pandang perempuan jauh lebih jeli. Kejelian itu yang sangat penting karena kebijakan-kebijakan yang diambil mensyaratkan keahlian lebih agar sesuatu dapat tercapai dengan optimal. Tujuan optimal merupakan isyarat keberhasilan sebuah penyelenggaraan program, dan keberhasilan sebuah program harus 
diapresiasi dan perlu diperhatikan keberlanjutannya.

\section{d. Kondisi Masyarakat dan Sosial Budaya}

Kondisi sosial masyarakat merupakan aspek yang sangat penting dalam pengelolaan pendidikan. Budaya sosial masyarakat menyentuh nilai-nilai dasar yang menjadi relasi yang mengikat sangat kuat dalam kehidupan bermasyarakat (Hofstede, 1991:23). Nilai-nilai dasar tersebut kemudian menjadi landasan filosofi dalam menjalani kehidupan. Sedangkan budaya organisasi dalam hal ini kepemimpinan vokasimerupakan wilayah praktis dari pengejawantahan nilai-nilai tersebut. Oleh karena itu, budaya atau kepemimpinan dalam suatu organisasi harus berlandaskan nilainilai yang sesuai dengan landasan hidup sosial masyarakat.

Dari sebuah studi kasus terkait kepemimpinan pendidikan di Hongkong menunjukkan bahwa di Hongkong terdapat seorang kepala sekolah yang membuat suatu terobosan baru dalam dunia pendidikan. Terobosan tersebut adalah dengan merubah gaya belajar yang sebelumnya mengadopsi pembelajaran yang berpusat kepada guru menjadi pembelajaran yang berpusat kepada peserta didik. keputusan tersebut kemudian menjadi perdebatan di parlemen. Akhirnya, keputusan rapat parlemen menyatakan bahwa tidakan yang dilakukan oleh kepala sekolah tersebut adalah sebuah pelanggaran. Hal ini dikarenakan kebijakan tersebut dianggap bertentangan dengan falsafah negara dimana etnis tianghoa harus memiliki tradisi siswa yang harus pasif dan menaati guru dalam kegiatan belajar (Dimmock, 2005:32).

Pesan moral yang dapat dipetik adalah kepemimpinan atau suatu kebijakan tidak boleh bertentangan dengan budaya masyarakat yang menjadi landasan kehidupan masyarakat. Dengan demikian, dapat dikatakan bahwa kepemimpinan pendidikan vokasi harus menjadi wadah pengejawantahan nilai-nilai dasar kehidupan masyarakat.

\section{SIMPULAN}

Berdasarkan pembahasan diatas, disimpulkan bahwa kepemimpinan merupakan faktor yang sangat penting dalam penyelenggaraan pendidikan vokasi. Kepemimpinan vokasi tidak ajeg dan absolut, melainkan sangat dinamis dan berbasis pada konteks yang mengikat kepemimpinan itu sendiri. Adapaun kontekstualisasi konsep dan gaya kepemimpinan tersebut adalah untuk menemukan efektifitas dan relevansi kepemimpinan dalam pencapaian hasil yang optimal.

Kepemimpianan pada lembaga pendidikan vokasi dengan tipe institusi besar akan efektif apabila menerapkan kepemimpinan distributif. Kepemimpinan pada lembaga yang berkapasitas sedang akan efektif dengan penerapan gaya kepemimpinan transformatif, dan kapasitas lembaga yang kecil akan sangat efektif dengan penerapan gaya kepemimpinan natural.

Selain itu, konteks tujuan pencapaian yang optimal, kepemimpinan vokasi dapat juga dipandang dari tiga aspek, adapaun ketiga aspek tersebut antara lain adalah : tipe isntitusi 
pendidikan vokasional, kepemimpianan dan penguasaan, kepemimpinan dan gender, serta kondisi sosial budaya masyarakat. Relevan dengan kesimpulan sebelumnya, aspek sudut pandang ini juga merupakan upaya dalam penyesuaian kepemimpianan yang optimal dalam pendidikan vokasional.

Dengan demikian, secara umum dapat disimpulkan bahwa gaya kepemimpinan yang efektif dalam rangka pelaksanaan program pendidikan vokasi yang sebelumnya ditetapkan sebagai program untuk pengembangan sumber daya manusia. Maka dari itu, kaya kepemimpian yang efektif juga dapat dijadikan sebagai alasan dilaksanakannya keberlangsungan program pendidikan vokasional Simpulan dapat bersifat generalisasi temuan sesuai permasalahan penelitian, dapat pula berupa rekomendatif untuk langkah selanjutnya.

\section{DAFTAR PUSTAKA}

Avery, Gayle C. (2004) Understanding Leadership. London, SAGE Publications

Beck, J. D. W. \& Yeager, N. M. (1994). The Leader's Window: Mastering the Four Styles of Leadership to Build HighPerforming Teams. New York: John Wiley \& Sons, Inc.

Dimmock, Clive \& Walker, Allan. (2005). Educational Leadership: Culture and Diversity. London: SAGE Publication Ltd Halim, Rosnarizah Abdul. (2015). Kepemimpinan Distributif, Faktor Kontekstual dan Efikasi Kendiri. Jurnal Kepemimpinan Pendidikan, Bil.2, Isu 4

Hallinger, Bickman, L., \& Davies, K. (1996). School context, principal leadership and student achievement. Elementary School Journal, 96(5), 527 - 549.

Hofstede, G. H. (1991). Cultures and Organizations: Software of the Mind. London: McGraw Hill.
ILO. (2011). Balai Latihan Kerja di Indonesia: Jalan Pintas Menuju Revitalisasi. Program Kementerian Tenaga Kerja dan Transmigrasi dalam rangka memperkuat sistem BLKI yang didukung oleh ILO. Jakarta: International Labour Organization.

MacBeath, J. (2005). Leadership as distributed: A matter of practice. School leadership and management, 25(45), $349-362$.

Philips, Knut Mitchell, D. E., \& Tucker, S. (1992). Leadership as a way of thinking. Educational Leadership. 49. 30-35.

Regina, (2010) Pengaruh Gaya Kepemimpinan, Motivasi dan Disiplin Kerja

terhadap Kinerja Karyawan (Studi pada PT Sinar Santosa Perkasa

Banjarnegara). Skripsi Universitas Diponegoro Semarang.

Seagren, A. T., Wheeler, D. W., Creswell, J. W., Miller, M. T. \& VanHom-Grassmeyer, K. (1994). Academic Leadership in Community Colleges. Lincoln: University of Nebraska Press.

Sehfudin, Arif. (2011). Pengaruh Gaya Kepemimpinan, Komunikasi Organisasi dan Motivasi Kerja Terhadap Kinerja Karyawan. FE Undip Semarang.

Spillane, J. P. (2006). Distributed Leadership. San Francisco: John Wiley \& Sons.

Sunarcaya, Putu. (2008). Analisis Faktor-Faktor yang Mempengaruhi Kinerja

Pegawai Di Lingkungan Dinas Kesehatan Kabupaten Alor Nusa

Tenggara Timur. Tugas Akhir Program Magister (TAPM). Universitas Terbuka Jakarta.

Syariati, Ali (1987). Tugas Cendikiawan Muslim. Jakarta: Penerbit CV. Rajawali

Tucker, A. (1992). Chairing the academic department: Leadership among peers. (3rd

ed.) New York: American Council on Education/Macmillan Series on Higher Education.

Wonacott, Michael E. (2001). Leadership Developmen in Career and Technical Education. ERIC Digest, EDO-CE-01225

Zed, Mestika (2008). Metode Penelitian Kepustakaan, Jakarta: Yayasan Obor Indonesia 